"the organic constituent of this substance may be considered to be derived from the decay of the various plants which grow on the moist moorlands above, and which, being carried by the waters into the fissures of the granite beneath, combines with the alumina of the decomposed felspar; and when it reaches the air deposits itself on the roof and sides of the caverns in the form of layers, varying from a line to two or three inches in thickness."

The mode of occurrence in the cave near Porthcurnow agrees with the description given by Mr. Jobnston: over the cave grow furze and bracken, and in the cave itself is a remarkable moss; fissures are visible in the roof at the farther end. The back of the cave gradually slopes towards the above-mentioned block.

The Pigotite is also found on the roof of the cave, but there has a different form, the surface being rippled and the ripple-marks being in some cases most distinct in cbaracter; in rare cases the form is serrated or dentated, and is suggestive of a mimicry of certain fossil remains, reminding one of the teeth of Ceratodus from the Rhætic beds (see Woodeut, p. 224). The frangibility of the mineral makes it difficult to obtain large specimens of any kind.

In the following month, from another cave only accessible at. certain tides, I obtained a small amount of Pigotite with somewhat different characters; it was more transparent, and in some cases of a rich yellow colour, in others ruby red; this kind has the general form of an efflorescence.

It may be hoped that the rediscovery of this mineral may induce some chemist to make a more complete examination of so extraordinary a compound.

\title{
INOTICES OF MFMOIRS.
}

On the Strocture of the French Alps. By Professor Marcel Bertrand. Translated from Comptes Rendus.

GOUR years' work in the Maurienne and Tarentaise at first led me to adopt the views of our Italian colleagues with regard to the "lustrous schists," and to consider them Palæozoic in age. This year, however, I have found conclusive sections which compel me to return to the old opinion of Lory, and to assign them to the 'Trias and even in part to the Lias. The proofs, which I shall give elsewhere, are closely connected with general conclusions on the structure of the region studied, and may even I believe extend to the whole chain. It is these which I wish to enumerate briefly here.

(1) The French Alps possess fan structure. The Carboniferous belt, stretching from Bourg St. Maurice to Briançon, is the centre of the fan. Along its edges on either hand there is a sort of narrow frontier zone in which the exact direction of overthrusting is uncertain; but, once this zone is passed, all the folds on the east 
side incline towards Italy, and all those on the west towards France.

The exceptions to this rule, such as the fans of Mont Blanc and St. Gothard, are infrequent and accidental. Side by side with classic sections of these massifs, which show fan structure, I believe that one could cite others, parallel, where it is wanting. Besides, such exceptions are only to be seen on the flanks of the "amygdaloidal massifs," to which I shall shortly refer."

Towards the north-east on reaching the (Swiss-Italian) frontier the central zone swells out considerably, so as to embrace the whole Monte Rosa massif; in this broadened zone the folds are not inclined in any one deterninate direction.

On the south the zone undergoes a more extraordinary change; instead of being occupied, as seems natural, by the most ancient rocks arranged in an anticlinal, it is made up of the most recent rocks, the nummulitic beds, and the flysch. The central zone is marked, geologically speaking at least, not by an uplift but by a depression. A preliminary note by MM. Kilian and Haug bas told us that in this new region (nummulitic band of Ubaye) there seem to be peculiarities altogether unique in the Alps-inclined folds of preEocene date. Possibly these peculiarities can be correlated with the great and sudden lowering of the central zone of the fan. However that may be, the Eocene band, from the point of view of the inclination of the folds, certainly plays the same part as the Carboniferous belt; all the western folds incline towards France, all the eastern ones towards Italy. Moreover, further on, the Mercantour massif, rising within the Eocene belt, marks a temporary return to a sharply anticlinal form. It seems to me, on comparing the folds of which the bearing is known in the intervening region, that the centre of the Alpine fan corresponds exactly with that of the Pyrenees.

(2) The plan of the folds in this part of the Alps shows an "amygdaloidal or beaded structure" (une structure amygdaloïde ou en chapelets), that is, the folds, while following the general trend of the chain, open out here and there round elliptical leuticles, themselves broken by new folds which have the same direction but are not prolonged beyond them. The system thus presents a series of nodes and ventral segments comparable with the foliation of an augen (amygdaloïde) gneiss, in which the folia bend round great kernels (noyaux) of quartz and felspar.

To give an idea of the importance of such kernels I will cite first

1 It is by virtue of this fan structure that the relatively recent date of the "lustrous schists" can be demonstrated. Throughout almost the entire range of these schists order of superposition proves nothing, because the structure is uniclinal. Fortunately certain great patches are still left on the summit of the fan. Thus not only is evidence of superposition perfectly clear, but it is such as to allow no other interpretation.

2 There would be, it is true, an important exception if the massifs of Annes, the Chablais, the Faulhorn, and the north fold of Glarus are, as is usually maintained, true anticlinal masses. This exception would disappear if they are overthrust masses. Thanks to the work of M. Schardt, attention is now definitely drawn to this problem, which I believe to be on the ere of solution. 
the example of Mont Blanc, a great kernel rising in the middle of a Liassic syncline, which shuts in round it. In the region to which I have devoted special attention, the Vanoise, Mont Pourri, with the Aiguille du Midi, the massif of the little Mont Cenis, and probably that of the Grand Paradis, all owe their existence to a like phenomenon; on the other hand, the massif of the great Sassière, and that of the Sana, are due to the sudden broadening of synclinals; in place of the ancient rocks it is the most recent ones which are here developed, but the system of folds sweeps round these widenings in just the same fashion and opens out and shuts in round them.

I do not think that we have, at least on a large scale, anything strictly comparable to this amygdaloidal structure, unless it be the crystalline region of the Lake of the Woods in America. Mr. Lawson derives one of his arguments from this structure to prove that the kernels formed of granitoid gneiss are eruptive in origin. Without contesting Mr. Lawson's conclusions on this ground we may point out froin the structure of our Alps that this argument, if it stood alone, would be valueless.

(3) A third conclusion is the generalization of that which $M$. Termier has already drawn from the study of Vanoise. On the east of the Carboniferous band metamorphism increases from west to east. I am driven, as was $M$. Termier in the Vanoise, to place confidently in the Permo-Triassic the ancient chloritic gneisses and mica schists of Mont Pourri, little Mont Cenis, and of the Val Grisanche, a continuation of the "Casanna schists" of Gerlach. Most of these arguments apply to the augen gneisses of the Grand Paradis, that is those which have been designated central gneiss; this would be a last term of the same metamorphism. It is to be noticed that in certain masses like the Dent Blanche and Monte Rosa we see, according to Gerlach, rising like an anticlinal from under this gneiss (or Casanna schist) still more ancient gneiss pierced by numerous granite veins, whilst such veins are absolutely wanting in the massifs previously cited; this is certainly a new argument. No region offers a more favourable field for continuing those micrographic studies so brilliantly inaugurated by M. Termier in the Vanoise, and it is to be hoped that we may be able to follow up in the formation and arrangement of the minerals all the stages to what it is at present convenient to term true gneiss.

This conclusion is analogous to that which M. Lossen has established for the ancient Hercynian Chain, where the Devonian in a similar central zone, situated, however, rather south of the centre, takes the form of mica schists and gneiss. It is right also to recall that M. Suess in 1869 made out a link between certain gneisses of the Carnic Alps and the Casanna schists in attributing a Permian age to them both.

I think it right to add that in favour of this last conclusion, at least in its general form, one can at present only give arguments, and not proofs, so that it is as well to separate it from the first twopropositi ons, which appear to me to be definitely established. 